\title{
Purification Study of Pervious Concrete Pavement
}

\author{
Ming-Ju Lee, Ming-Gin Lee, Yishuo Huang, and Chia-Liang Chiang
}

\begin{abstract}
Pervious concrete pavement is an effective means to address important environmental issues and support green and sustainable growth. By capturing storm water and allowing it to seep into the ground, pervious concrete is instrumental in recharging groundwater, reducing storm water runoff, and meeting U.S. Environmental Protection Agency storm water regulations. In fact, the use of pervious concrete is among the Best Management Practices recommended by the EPA.

In this research, water quality and pollutants leached from pervious concrete pavement was investigated. This project mainly aims to study the pervious concrete pavement by pollutants such as acid rain, sea water or waste lubricating oil. The results show that pollutant and water purification of pervious concrete pavement both significantly improved in the acid rain, sea water or waste motor oil test. A diluted sulfuric acid solution ( $\mathrm{pH}$ value 2.0) after the pervious concrete pavement system could significantly enhance its $\mathrm{pH}$ value to 6.5 above. This study demonstrates that implementing pervious concrete pavement is valuable for road design and hydrologic consideration.
\end{abstract}

Index Terms-Pervious concrete, water purification, acid rain, waste motor oil.

\section{INTRODUCTION}

Pervious concrete pavement is ideal for protecting trees in a paved environment. Many plants have difficulty growing in areas covered by impervious pavements, sidewalks, and landscaping, because air and water have difficulty getting to the roots. Pervious concrete allows adjacent trees to receive more air and water while still permitting full use of the pavement. Pervious concrete provides a solution for landscapers and architects who wish to use greenery in parking lots and paved urban areas [1]. The pervious concrete pavement possesses many advantages that improve city environment as follows by EPA [2]:

1) Water treatment by pollutant removal.

2) Less need for curbing and storm sewers.

3) Improved road safety because of better skid resistance

4) Recharge to local aquifers.

Pervious concrete is a special type of concrete with a high porosity used for concrete flatwork applications that allows water from precipitation and other sources to pass through it,

Manuscript received January 31, 2013; revised May 22, 2013. This work was supported in part by the R.O.C. Ministry of Transportation and Communications under grant MOTC-IOT-99-H1DB005. (Sponsor and financial support acknowledgment goes here).

Ming-Ju Lee is with the Jen-Teh Junior College of Medicine, Miaoli, Taiwan (email: mingju6099@yahoo.com.tw).

Ming-Gin Lee and Yishuo Huang were with University of Florida, Gainesville, FL 32601 USA. They are now with the Department of Construction, Chaoyang University of Technology, Taichung 41349, Taiwan (corresponding author's e-mail: mglee@cyut.edu.tw, yishuo@cyut.edu.tw).

Chia-Liang Chiang is with the Department of Construction, Chaoyang University of Technology, Taichung 41349, Taiwan (e-mail: banana333sky@yahoo.com.tw). thereby reducing the runoff from a site and recharging ground water levels. The void content can range from 18 to $35 \%$ with compressive strengths of 400 to 4000 psi (2.8 to $28 \mathrm{MPa})$. The drainage rate of pervious concrete pavement will fall into the range of 2 to $18 \mathrm{gal} / \mathrm{min} / \mathrm{ft}^{2}\left(81\right.$ to $\left.730 \mathrm{~L} / \mathrm{min} / \mathrm{m}^{2}\right)$. Typically pervious concrete has little to no fine aggregate and has just enough cement paste to coat the coarse aggregate particles while preserving the interconnectivity of the voids [3]. Pervious concrete is traditionally used in parking areas, areas with light traffic, pedestrian walkways, and greenhouses. Pervious Concrete is an important application for sustainable development [4]. The study results of the pervious concrete on parking lot in Taiwan composed of 8-in surface layer (pervious concrete) and a 4-in base layer (gravel) showed that the compression strength of the surface layer exceeds the ordinary concrete structure specification (175 $\mathrm{kg} / \mathrm{cm}^{2}$ ). The field permeability test for the parking lot is about $1000 \mathrm{ml} / 15 \mathrm{sec}$. The water penetration of the above pervious concrete is very good and no cracks were present on surface [5].

Roadways and parking lots are large contributors to non-point source pollution. Suspended solids, heavy metals, and hydrocarbons are distributed over pavement surfaces by automobile exhaust and crankcase leakages [6]. Automobile pollutants accumulate on road surfaces until a precipitation event carries these pollutants away in runoff that eventually enters waterways or groundwater [7]. These pollutants can potentially damage sensitive ecosystems in nearby bodies of water or enter the water supply through wells and surface water withdrawals, which can be detrimental to human health. Various water quality studies of permeable concrete pavement systems report pollutant removal in storm water. According to these studies, permeable concrete pavement systems may filter out, trap, and biodegrade oil [8]. The addition of oil degrading bacteria is not necessary for bacterial utilization of oil; the indigenous bacteria are capable of degrading the oil on their own. In some cases where oil was efficiently degraded, nutrients were needed to promote the oil degrading activity of the bacteria. As the nutrient level declined so did carbon dioxide levels, which indicate bacterial activity [8]. Before claims can be made that oil is sufficiently degraded in pervious pavement, a feasible method of slowly releasing nutrients into the pervious pavement might need to be developed that will last the lifetime of the pavement. Research has been started to implement slow release phosphate beads into designs [7], but field testing should also be performed to verify laboratory results. As microorganism diversity increases in pavement structures so does the utilization rate of oil. This phenomenon is not well understood and more research is needed to determine why the optimum oil degrading activity occurs with higher diversity even though the oil is only observed to be degraded by bacteria [8]. A great number of continuous 
voids formed inside the water permeable concrete and its wide specific surface area are effective in the aspect of water purification by providing inhabitation space for phytoplankton, bacteria and living organisms [6]. However, a research and development study is needed to determine the method to improve the water purification performance against the inflow of a large amount of wastewater and harmful substances and to solve these problems. The study of water quality and pollutants leached from pervious concrete pavement was undergoing. This project mainly aims to study the pervious concrete pavement by pollutants such as acid rain, sea water or waste lubricating oil.

\section{EXPERIMENTS}

\section{A. Pervious Concrete Material and Concrete Specimen}

The cement used in this study was type I Portland cement conforming to ASTM C 150 which was manufactured by the Taiwan cement company. The coarse aggregate used was a commonly-used crushed stone with maximum diameter of 6 $\mathrm{mm}$. Fine aggregates are nonexistent in pervious concrete mixture because they tend to compromise the connectedness of the pore system. The superplasticizer (SP) is liquid and its specific gravity is 1.05 and has $30 \%$ solid content. The above materials including cement, crushed gravel, SP, and water were used to make the pervious concrete mixtures with zero-inch slump. Fig. 1 shows fresh and non-sag pervious concrete. Two different compaction methods were named: tamping rod (ASTM C 192) and Proctor method (identified in this research as Proctor modified). Proctor modified method is applied with a steel circular plate bonded to a rod guide which work as a rail for the plate. To compact the concrete, the plate must run all the rod way, and charge all the weight over the concrete surface by free-fall [7]. The specimen is filled in 2 layers, each one is compacted by 25 tamps, keeping the height of the plate (Fig. 2).

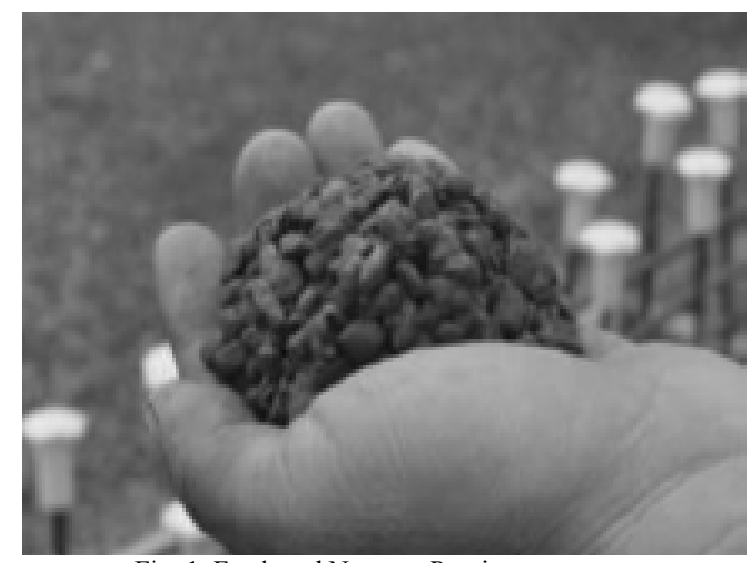

Fig. 1. Fresh and Non-sag Pervious concrete

The pervious concrete specimen, its area was 18 inch by 12 inch, was used to simulated pavement material as surface layer and to measure the in-place water permeability. The in-place water permeability test was displayed in Fig. 3. The simulated surface layer specimens were placed with 4 inch, 6 inch and 8 inch thick pervious concrete respectively and compacted by the roller weighs approximately $220 \mathrm{lb}$ (100 $\mathrm{kg}$ ). The roller is not recommended for larger placements due to the extended rolling time required that could lead to raveling failures. After the strength and permeability tests, the samples were taken from each of the simulated pavement specimens for water pollutant testing.

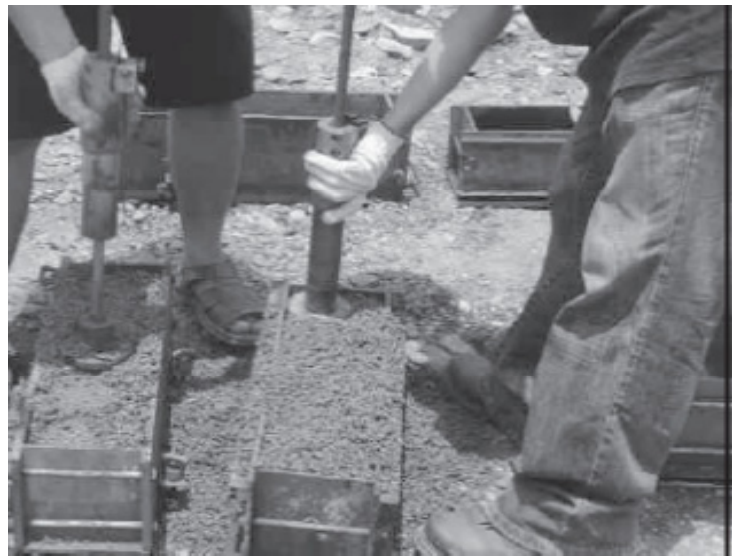

Fig. 2. Proctor Modify Compaction Method

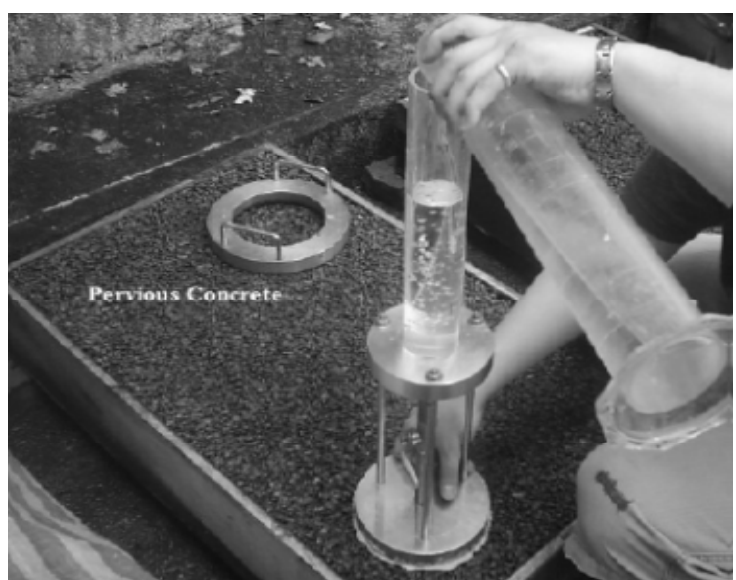

Fig. 3. In-place Water Permeability Test

\section{B. Pervious Pavement Test Box and Water Pollutant Test variables}

The pavement test box was set up in glass box having a plane area 12 -inch by 18 -inch of 4 -inch to 6 -inch thick pervious concrete as surface layer and a 6 -inch base layer (gravel) overlaying a 6-inch sub-base layer (soil) with an infiltration rate estimated to be $0.1 \mathrm{inch} / \mathrm{sec}$. A geotextile membrane separated gravel and soil from the underlying sub-base. Each glass box had a 2-inch diameter pipe at bottom (sub-base) layer for the collection of the effluent samples, and also had a 2-inch diameter pipe at middle (base) layer. At the pipe outlet, a tap was fixed, preventing unintentional effluent loss. Only a 12 -inch $\times 12$-inch area of the surface was used for waste oil application.

The water pollutant tests and variables used in the experiment are shown in Table I. The water-cement ratio of the pervious concrete was fixed at $23 \%$. Three different thickness of pervious concrete were 4 inch, 6 inch and 8 inch respectively. In addition, three water pollutants to be used were seawater, diluted sulfuric acid and waste oil. The amount of water pollutant be used to pour over the surface layer were 5 liter, 10 liter, 15 liter and 20 liter, respectively. Fig. 4 shows two pervious concrete pavement systems in this study. Two different pavement layers (base layer and sub-base layer) and five different test items (compressive strength, flexural strength, salt content, oil content and $\mathrm{pH}$ value) were incorporated in the water pollutant experiment. 
TABLE I: TEST VARIABLES USED IN THE EXPERIMENT

\begin{tabular}{ll}
\hline \hline Experimental Content & Variables \\
\hline Thickness of Pervious Concrete & $10,15,20(\mathrm{~cm})$ \\
& Surface layer (pervious concrete), \\
Pervious Concrete Pavement & Base layer (gravel), \\
& Sub-base layer (soil) \\
Pollutant Items & Seawater, Waste Oil, \\
Pollutant Volume & Diluted Sulfuric Acid Solution \\
& $5,10,15,20$ (liter) \\
Test Items & Compressive Strength, \\
& Flexural Strength, pH Value, \\
& Salt Content, Oil Content \\
\hline \hline
\end{tabular}

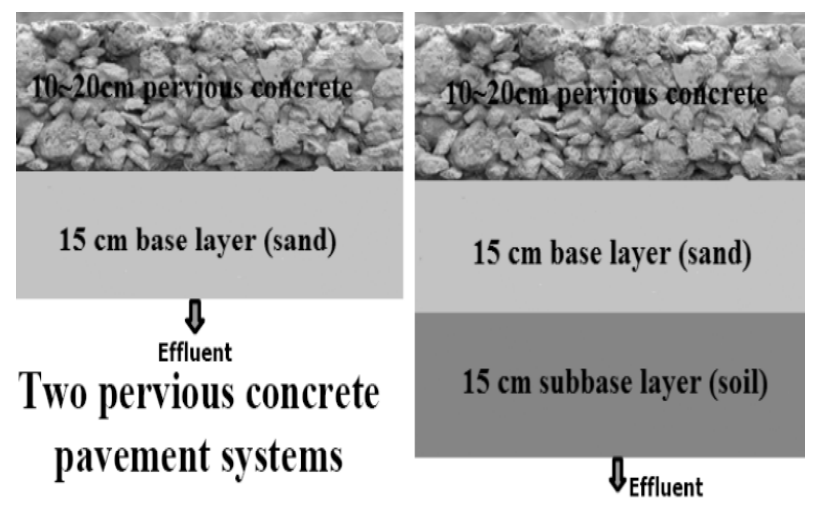

Fig. 4. Two Pervious Concrete Pavement Systems

\section{RESUlTS AND DisCUSSION}

\section{A. Strength and Water Penetration Testing}

One of the most important features of pervious concrete is its ability to penetrate water through the open pore structure. The penetration rate of pervious concrete is directly related to the air void content. Because the penetration rate increases as air void content increases, and, consequently, compressive strength decreases, the challenge in pervious concrete mixture proportioning is achieving a balance between an acceptable penetration rate and an acceptable compressive strength [9]. The water penetration coefficient of pervious concrete can be measured by a simple falling head permeameter. The 7-day, 28-day and 56-day water penetration test results are recorded in Table II. The flow rates for water through pervious concrete ranged from 0.27 $\mathrm{cm} / \mathrm{sec}$ to $0.34 \mathrm{~cm} / \mathrm{sec}$. The field water permeability test results are also recorded in Table II. The water permeability of pervious concrete specimens ranged from 1091 to 1200 $\mathrm{ml} / 15 \mathrm{sec}$ after installation. A steady small decrease in water penetration coefficient and water permeability was found as the curing time of pervious concrete increase.

TABLE II: STRENGTH AND WATER PENETRATION RESUlTS FROM PERVIOUS CONCRETE SAMPLES

\begin{tabular}{lllll}
\hline \hline $\begin{array}{l}\text { Curing } \\
\text { Duration }\end{array}$ & $\begin{array}{l}\text { Compressive } \\
\text { Strength } \\
\left(\mathrm{kg} / \mathrm{cm}^{2}\right)\end{array}$ & $\begin{array}{l}\text { Flexural } \\
\text { Strength } \\
\left(\mathrm{kg} / \mathrm{cm}^{2}\right)\end{array}$ & $\begin{array}{l}\text { Coefficient of } \\
\text { Penetration } \\
(\mathrm{cm} / \mathrm{sec})\end{array}$ & $\begin{array}{l}\text { Water } \\
\text { Permeability } \\
(\mathrm{ml} / 15 \mathrm{sec})\end{array}$ \\
\hline 7-day & 97.85 & 14.25 & 0.34 & 1200 \\
28-day & 86.52 & 16.04 & 0.31 & 1105 \\
56-day & 98.78 & 12.21 & 0.27 & 1091 \\
\hline \hline
\end{tabular}

The results of the pervious concrete pavement test box by waste oil penetration studies are presented in Table V. It can be seen that the oil content decreases substantially as the thickness of pervious concrete increases at both base layer and sub-base layer. Waste motor oil with certain water after the pervious concrete pavement test box could significantly reduce its oil content to $1 \%$. In the case of the pervious concrete pavement test box at sub-base layer had more removal oil capacity than in the case of the pervious concrete pavement test box at base layer.

\section{B. Pervious Pavement Test Box and Water Pollutant Test variables}

Permeable concrete pavements such as pervious concrete have also been reported to remove heavy metals from infiltrating water without the danger of mobilization [7]. The alkalinity in concrete raises the $\mathrm{pH}$ of infiltrating water, which may cause most heavy metals to precipitate as metal hydroxides and remain in or around the concrete layer or in the base material [7]. Pervious concrete systems were reported to have reduced the amount of total nitrogen by $37-95$ percent as well as reduce the total phosphorous by 66-95 percent [11].

A study on the effects of concrete thickness, pollutant content, seawater, diluted sulfuric acid, waste motor oil and soil layer on the penetration of pervious concrete pavement test box in laboratory was conducted. The results of the pervious concrete pavement test box by seawater penetration studies are presented in Table III. It can be seen that the salt content decreases substantially as the thickness of pervious concrete increases at the sub-base layer. A seawater solution (salt content $3.6 \%$ ) after the pervious concrete pavement test box could significantly decrease its salt content to $0.1 \%$ at sub-base layer (soil) but seem unchanged at base layer (gravel).

TABLE III: SAlt Content Results of Pervious Concrete PaVEMENT TEST BOX By SEAWATER PENETRATION

\begin{tabular}{lccc}
\hline \hline \multirow{2}{*}{ Seawater (liter) } & \multicolumn{3}{c}{ Thickness of Pervious Concrete (Base Layer) } \\
& $10 \mathrm{~cm}$ & $15 \mathrm{~cm}$ & $20 \mathrm{~cm}$ \\
\hline 5 & $3.40 \%$ & $3.40 \%$ & $3.25 \%$ \\
10 & $3.43 \%$ & $3.40 \%$ & $3.30 \%$ \\
15 & $3.43 \%$ & $3.43 \%$ & $3.30 \%$ \\
20 & $3.50 \%$ & $3.50 \%$ & $3.50 \%$ \\
\hline \hline \multirow{2}{*}{ Seawater (liter) } & Thickness of Pervious Concrete (Sub-base Layer) \\
& $10 \mathrm{~cm}$ & $15 \mathrm{~cm}$ & $20 \mathrm{~cm}$ \\
\hline 5 & $1.35 \%$ & $1.30 \%$ & $0.10 \%$ \\
10 & $2.00 \%$ & $1.45 \%$ & $0.20 \%$ \\
15 & $2.20 \%$ & $1.73 \%$ & $0.30 \%$ \\
20 & $2.38 \%$ & $1.83 \%$ & $0.35 \%$ \\
\hline \hline
\end{tabular}

The results of the pervious concrete pavement test box by diluted sulfuric acid solution penetration studies are presented in Table IV. It can be seen that the $\mathrm{pH}$ value increases substantially as the thickness of pervious concrete increases at both base layer and sub-base layer. A diluted sulfuric acid solution ( $\mathrm{pH}$ value 2.0) after the pervious concrete pavement test box could significantly enhance its $\mathrm{pH}$ value to 6.93. In the case of the pervious concrete pavement test cell at sub-base layer had more diluted acid effect than in the case of the pervious concrete pavement test box at base layer.

The results of the pervious concrete pavement test box by waste oil penetration studies are presented in Table V. It can be seen that the oil content decreases substantially as the thickness of pervious concrete increases at both base layer 
and sub-base layer. Waste motor oil with certain water after the pervious concrete pavement test box could significantly reduce its oil content to $1 \%$. In the case of the pervious concrete pavement test box at sub-base layer had more removal oil capacity than in the case of the pervious concrete pavement test box at base layer.

TABLE IV: PH VAlue Results of PeRvious Concrete PaVement Test BoX By Diluted Sulfuric ACid Solution (PH VAlue 2.0) Penetration

\begin{tabular}{lccc}
\hline \multirow{2}{*}{$\begin{array}{l}\text { Diluted Sulfuric } \\
\text { Acid (liter) }\end{array}$} & \multicolumn{3}{c}{ Thickness of Pervious Concrete (Base Layer) } \\
\hline 5 & 4.29 & 5.53 & 6.39 \\
10 & 4.61 & 5.85 & 6.30 \\
15 & 5.33 & 5.94 & 6.08 \\
20 & 5.45 & 6.05 & 5.92 \\
\hline \hline Diluted Sulfuric & \multicolumn{3}{c}{ Thickness of Pervious Concrete (Sub-base Layer) } \\
Acid (liter) & $10 \mathrm{~cm}$ & $15 \mathrm{~cm}$ & $20 \mathrm{~cm}$ \\
\hline 5 & 5.86 & 6.85 & 6.93 \\
10 & 6.12 & 6.72 & 6.69 \\
15 & 6.21 & 6.20 & 6.22 \\
20 & 6.24 & 6.10 & 6.25 \\
\hline \hline
\end{tabular}

TABle V: Oil Content Results of Pervious Concrete PaVement Test BoX By Waste Motor Oil Penetration

\begin{tabular}{lccc}
\hline \hline \multirow{2}{*}{ Water (liter) } & \multicolumn{3}{c}{ Thickness of Pervious Concrete (Base Layer) } \\
& $10 \mathrm{~cm}$ & $15 \mathrm{~cm}$ & $20 \mathrm{~cm}$ \\
\hline 5 & $2.51 \%$ & $2.72 \%$ & $2.90 \%$ \\
10 & $2.93 \%$ & $2.47 \%$ & $2.08 \%$ \\
15 & $3.24 \%$ & $1.94 \%$ & $1.84 \%$ \\
20 & $3.51 \%$ & $1.82 \%$ & $1.71 \%$ \\
\hline \hline Water & \multicolumn{4}{c}{ Thickness of Pervious Concrete (Sub-base Layer) } \\
(liter) & $10 \mathrm{~cm}$ & $15 \mathrm{~cm}$ & $20 \mathrm{~cm}$ \\
\hline 5 & $3.79 \%$ & $2.40 \%$ & $1.00 \%$ \\
10 & $2.67 \%$ & $2.31 \%$ & $1.00 \%$ \\
15 & $2.48 \%$ & $2.12 \%$ & $1.11 \%$ \\
20 & $2.48 \%$ & $1.72 \%$ & $1.41 \%$ \\
\hline \hline
\end{tabular}

\section{SUMMARY}

The results of pervious concrete specimens showed that the water penetration increases as the duration increases, but both compression strength and flexural strength seem unchanged as the duration increases. A seawater solution (salt content $3.6 \%$ ) after the pervious concrete pavement test box could significantly decrease its salt content to $0.1 \%$ at sub-base layer (soil) but seem unchanged at base layer (gravel).

A diluted sulfuric acid solution ( $\mathrm{pH}$ value 2.0 ) after the pervious concrete pavement test box could significantly enhance its $\mathrm{pH}$ value to 6.93 . In the case of the pervious concrete pavement test cell at sub-base layer had more diluted acid effect than in the case of the pervious concrete pavement test box at base layer.

Waste motor oil with certain water after the pervious concrete pavement test box could significantly reduce its oil content to $1 \%$. In the case of the pervious concrete pavement test box at sub-base layer had more removal oil capacity than in the case of the pervious concrete pavement test box at base layer. The test results show that water purification and pollutant of pervious concrete pavement both significantly improved in the acid rain, sea water or waste lubricating oil test.

\section{ACKNOWLEDGMENT}

The authors would like to thank the Ministry of Transportation and Communications for the financial support under the grant MOTC-IOT-99-H1DB005.

\section{REFERENCES}

[1] P. Tennis, M. L. Leming, and D. J. Akers, Pervious Concrete Pavements, EB 302, Portland Cement Association (PCA), Skokie, Illinois, pp. 1-25, 2004.

[2] J. Yang and G. Jiang, "Experimental study on properties of pervious concrete pavement materials," Cement Concrete Research, vol. 33, no. 6, pp. 381-386, 2003.

[3] National Ready Mixed Concrete Association, Freeze Thaw Resistance of Pervious Concrete, Silver Spring, MD, pp. 1-17, 2004.

[4] K. Obla, "Pervious concrete for sustainable development," in Proc. $1^{\text {st }}$ Int. Conf. on Recent Advances in Concrete Technology, Washington DC, 2007.

[5] M. G. Lee, C. T. Chiu, Y. Kan, and T. Yen, "Experimental study of pervious concrete on parking lot," ASCE Geotechnical Special Publications, vol. 193, pp. 125-131, 2009.

[6] S. B. Park, B. J. Lee, J. Lee, and Young Il Jang., "A study on the seawater purification characteristics of water-permeable concrete using recycled aggregate," Resources, Conservation and Recycling, vol. 54, pp. $658-665,2010$.

[7] J. N. Thomle, "The declining ph of waters exposed to pervious concrete," Master thesis, Washington State University, Department of Civil and Environmental Engineering, 2010.

[8] A. P. Newman, C. J. Pratt, and N. Cresswell, "Oil bio-degradation in permeable pavements by microbial communities," Water Science and Technology, vol. 45, no. 7, pp. 51-56, 2002.

[9] ACI 522R-06, "Pervious concrete," American Concrete Institute, Farmington Hills, MI, pp. 1-25, 2006.

[10] M. G. Lee, C. T. Chiu, and T. Yen, "Application of pervious concrete on transportation engineering (2/2)," Ministry of Transportation and Communications, Taiwan, pp. 1-188, 2008.

[11] M. J. Lee, M. G. Lee, Y. Huang, and C. L. Chiang, "Water purification of pervious concrete pavement," in Proc. Int. Conf. on Sustainable Design, Engineering, and Construction, Fort Worth, Texas, 2012.

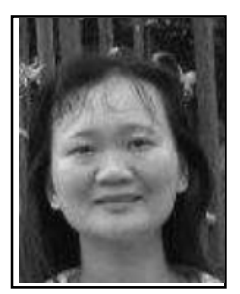

Ming-Ju Lee was born in Taiwan, where she received both her Bachelor of Science degree and Master degree in Applied Mathematics Department from National Central University. She received her $\mathrm{PhD}$ in Applied Mathematics Department from National Central University in 2006. She is an Assistant Professor in the Jen-Teh Junior College of Medicine, Miaoli, Taiwan, R.O.C. Her research interests include applied mathematics and theory analysis.

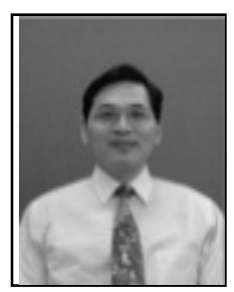

Ming-Gin Lee was born on October 14, 1960, in Taiwan, where he received both his Bachelor of Science degree and Master degree in Civil Engineering. $\mathrm{He}$ received his $\mathrm{PhD}$ in Civil Engineering from University of Florida, Gainesville, FL, in 1996. He is a Professor in the Department of Construction Engineering at Chaoyang University of Technology, Taichung, Taiwan. His research interests include concrete materials and innovation of construction materials.

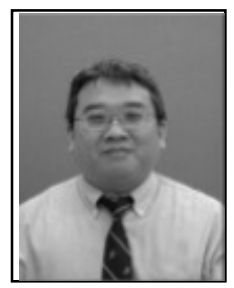

Yishuo Huang was born in Taiwan, where he received his Bachelor of Science degree in Civil Engineering. He received his Master degree in Civil Engineering from University of Wisconsin-Madison, Madison, WI, in 1992. He received his $\mathrm{PhD}$ in Civil Engineering from University of Florida, Gainesville, FL, in 1996. He is an Assistant Professor in the Department of Construction Engineering at Chaoyang University of Technology, Taichung, Taiwan. His research interests include Digital Photogrammetry, Data Visualization and Spatial Data Analysis (e-mail: yishuo@cyut.edu.tw).

Chia-Liang Chiang was born in Taiwan, where he received both his Bachelor of Science degree and Master degree in Construction Engineering from Chaoyang University of Technology, Taichung, Taiwan. He has just finished one year of military service and trying to find a job. 